\title{
BASIC PRINCIPLES OF CREATING MOBILE LEARNING CONTENT FOR THE DEVELOPMENT OF FUTURE TEACHERS ENGLISH LANGUAGE COMPETENCE
}

\author{
Olena Iaburova \\ Candidate of Pedagogical Sciences, Associate Professor of \\ Primary Education Theory and Practice Department \\ SHEI "Donbass State Pedagogical University" \\ Sloviansk, Donetsk Region, Ukraine \\ ORCID ID 0000-0003-4633-2900 \\ primetime3311@gmail.com
}

\begin{abstract}
The article is devoted to the actual issue - the implementation of mobile learning tools in the process of forming English language competence of future teachers and the creation of mobile learning content according to its main principles. The author analyzes modern views on mobile learning as a specific type of e-learning having its own advantages and disadvantages, studies the research works of foreign and Ukrainian scientists S. Semerikov, K. Buhaichuk, M. Kyslova, A. Stryuk, M. Stryuk, M. Bransford, J. Douglas, J. Traxler and others.

The author has provided the own concept of mobile learning and formulated basic principles of creating mobile learning content as the article's goal. More than that, the author has determined the place of mobile learning in the system of future teachers training and outlined the perspectives of further use of mobile learning content in the form of mobile sites, blogs, applications and platforms to build the English language competence of future teachers during classroom and extra-curriculum activities. Leading research methods used: theoretical methods of scientific knowledge (analysis and synthesis, generalization and deduction), methods of empirical level (observations and descriptions).

The basic principles of creating mobile learning content for the formation of future teachers language competence are described. The necessity of chunking the course material as the most effective way of mobile learning and memorizing techniques are pointed out. The set of basic rules to organize the mobile course content with the focus on micro learning, ultimate flexibility, learnercentered approach, facilitating the interest in the subject, organizing simple visuals are presented. More principles under the article's author attention are mobile mentoring and micro assessments which can provide more real-time, context-aware training opportunities for the formation of future teachers competence in English language.

It is noted that the research is practical since it gives a detailed description of the basic principles of creating mobile learning content and its implementation in the process of future teachers training. It is important that the forms, methods and basic principles of mobile learning join Ukrainian students to the global process of education informatization and demonstrate further perspectives in the formation of their English language competence.
\end{abstract}

Key words: mobile learning; mobile learning surrounding; mobile content; future teachers, English language competence.

Problem setting in general. Rapid development of modern ICT technologies opens a wide range of opportunities for effective and efficient organization of the academic process at higher educational establishments and the achievement of positive 
results. Being a mainstream, which uncovers new dimensions of learning and personal growth, mobile phones have completely dominated over interactive learning from gaining new information, activating and refreshing knowledge to performance of testing and final assessing, thus, becoming a sound approach to a number of longstanding educational issues.

Mobile devices such as smartphones and tablets allow to access digital content in a very personalized manner, participate in distant learning course without any limitations or restrictions, connect billions of learners worldwide creating a very beneficial learning environment for the global network of learners. Mobile devices have the power to function as an effective connection between individuals and groups of people being educated through discussion forums, blogs and social values. Today's mobile technology is increasingly improving students' performance through contextual learning and gaining acceptance as an effective tool within the students and university lecturers community because of its simplicity, smoothness, efficiency, costeffectiveness, and minimal time-consumption.

Meanwhile, the analysis of scientific literature reveals the signs of further researching necessity in the fields of defining the content of mobile learning, clarifying particular components of mobile learning techniques, pointing out positive and negative aspects of using mobile devices, developing teaching approaches to implementing mobile learning in various university courses.

The latest papers and publications on the problem. The issues of using innovative technologies, mobile telephones in particular, in the process of future teachers training while forming the components of their professional competence are observed in the numerous scientific works. Foreign researchers give more detailed description and explanation of mobile learning techniques whereas this issue of scientific interest is not researched deeply in Ukraine. The analysis of Ukrainian and foreign experience of using mobile devices leads to the conclusion of insufficient theoretical background development, inadequate methodical approaches to using mobile learning technology (Department of Education and Science, 2000; Learning for life: Paper on Adult Education). The necessity of finding the balance between didactic possibilities of mobile learning and the lack of scientists attention to the issues of projecting mobile learning techniques defines the relevance of regarding the issues of this kind of learning technologizing, which provides the development of future specialists, namely teachers, professional competences.

Defining the main idea, principles, and didactic possibilities of mobile learning, it should be pointed out that this way of educating is characterized as the learning technology which uses mobile devices in the process of classroom and extracurriculum activities to provide the lecturers and students with the access to information, to organize students-lecturers mutual communication and interaction, and to provide unlimited possibilities for students to revise the material on a constant base (Geddes, 2004). 
These peculiarities mentioned above allow to enhance the understanding of lifelong education phenomenon which accompanies students in the process of the whole life-activity. Lifelong education is the ongoing, voluntary, and self-motivated knowledge gaining for both personal and professional activity, which enhances social inclusion, active citizenship, personal development as well as competitiveness, selfsustainability and employability (Commission of the European Communities: "Adult learning: It is never too late to learn" COM (2006) 6/4 final. Brussels, 23.10.2006). The concept of life-long education has been under the process of continuous change because of the increased duration of formal education and insufficiency of skills attained in schooling for future career and success.

Continuing the ideas of the importance of life-long education formulated by M. Bransford and J. Douglas (2000) it is essential to point out the position of J. Traxler (n.d.) according to which mobile devices used in the process of education significantly change the form of knowledge gaining, develop the geographical possibilities of educational process participants location and benefit the new forms of material presentation.

Chinese scientists are actively involved in the process of mobile-learning development and consider the first mobile project "Theory and Practice of Mobile Learning" patronized by the Centre for Education Technology, Peking University and the Ministry of Education of China as a prospective way of effective learning. They have given a detailed description of the current situations, have studied the results of mobile learning, have explored the characteristics and prospects of the implementation of mobile learning platforms.

Analyzing the peculiarities of mobile learning implementation, its advantages and disadvantages, S. Semerikov (2015) points out the results of the perspectives in the field of mobile learning involvement in the process of education on the basis of statistics data of using mobile devices, mobile educational programs, and wireless access. According to the author, the main types of mobile content during mobile learning are considered to be mobile sites, mobile applications, adapted e-tools of educational purposes, social nets, and unique content of virtual reality.

Observing educational mobility from the position of systematic approach, M. Striuk and A. Striuk (2015) underline the main tendencies of academic mobility development (from students' mobility to mobile programs and educational service suppliers) and characterize new programs which are aimed at raising academic mobility. The authors observe a new kind of mobility supplying and focus the attention on virtual universities that are now the base for students virtual mobility development and the main activity of which is based on modern ICT technology using, mainly the Internet and educational mobile environment.

M. Kyslova and K. Slovak (2015) propose the own methodical approach to illustrate using the educational mobile environment in the field of mathematics, built on the platform Google Apps Education Edition. They observe the main ways of using educational mobile environment, in particular giving educational tables, making 
calculations, visualizing mathematical phenomena, developing skills of doing mathematical research, offering the automatic system of control and assessment of students results, supporting students educational activity, and organizing students extra-curriculum activity (Kyslova, 2015). Thus, it can be emphasized that in the process of educational activity at the higher educational establishment mobile learning environment fulfils a lot of important functions such as forming the system of knowledge, modelling particular learning activities and skills to do scientific research, activating students' communication and interaction.

K. Buhaichuk (2012) points out the fact that mobile learning in the system of education can be regarded as one of the distant learning types, but at the same time it has similar features with electronic learning. According to the author's point of view, mobile learning can be characterized as the process of learning in the conditions of the student's mobile access to educational resources, the interaction with the lecturer and other students by the means which are provided by these resources. Besides, mobile learning is based on the principles of flexibility, module division, independence from the time and place, and the involvement of modern ICT technologies.

Having analyzed the mentioned above resources, the author can conclude that foreign and Ukrainian scientists underline the importance of learning process to be organized in the mobile form which involves a lot of positive characteristics of distant learning and, at the same time, avoids its main disadvantages. Among various mobile learning environment, the author points out m-learning as the latest and the most effective and instructive one. Meanwhile, the problem of creating mobile learning content for teaching English has not been researched enough and the issues of formulating basic principles of mobile learning contact, the influence of this type of education on future teachers key competences, in particular English language competence should be analyzed more deeply.

Putting aims of the article (tasks). The aim of the article is to generalize the main idea, content, and methods of mobile learning (analysis of foreign experience and the perspectives of implementing the mentioned above technologies in the Ukrainian educational environment, defining the basic principles of mobile learning content creation) and empirical studying of mobile learning effectiveness in the modern educational environment with the aim of further mobile learning content improvement.

Results of the study. Education as the main fact of society development should be flexible enough to be adapted to the conditions of the modern world. Thus, the emergence of ICT technologies was the base for computerizing the learning process at higher educational establishment. Net technologies activated involving all educational establishments into the Internet surrounding and implementing distant learning by the means of e-mail communication, conferences, forums, and mobile platforms for operating distant learning and using mobile devices.

Mobile learning is regarded as the new stage of e-learning development which uses mobile devices and wireless access to educational resources as the means of education. The peculiarity of mobile learning in comparison with other systems of 
education is the use of any mobile device as the main means of education which does not limit the student with the classroom environment. So, mobile learning is considered to be one of the best way to increase the productivity of the teacher work and students' motivation.

Every type of the content and its effectiveness and productivity can be characterized by different mobile environment descriptions:

- mobile sites are the most widespread ways to give access to learning materials nowadays. This site can include the blog of content navigation, the lecture page, the platform for distant learning. These sites use a simple way of presenting educational information adapted to the system of mobile devices and normally do not have a lot of additional functions.

- mobile application is the main program support which is used in smartphones, tablets and other mobile devices. Mobile applications give an opportunity to check email correspondence, look through mobile content, and communicate with other people by the means of the various messengers such as Viber or Gmail. The peculiarity of educational mobile applications, besides educational content is the system of informing that motivates students to work on the new pieces of material and the possibility of offline work in case of downloading the files.

- popular social nets can be realized through mobile devices. Besides entertainment functions, social nets can be used in education. They give opportunities to exchange data at ease, upload and download educational material about important events, present students research work for general observation.

In spite of mobile learning advantages, higher educational establishments in Ukraine are not ready for using smartphones and mobile technologies as the way to increase the effectiveness of students learning. Creating content for the mobile presentation requires the information of the course to be divided into highly readable, clearly understandable and briefly presented bits of material called "chunks". Chunking which is used for a wide range of learning and memorizing techniques is an appealing and effective way to move the process of ongoing gaining material from traditional learning methods like computer screens, textbook or lectures to active mobile learning involvement.

The best thing about well-targeted microlearning is that it offers students the ultimate flexibility to choose their own place and time of task completion that can be regarded as a completely learner-centered approach. There is a set of basic rules to follow while organizing the mobile course content:

- organize chunks according to their patterns and similarities;

- include simple visuals written with minimal text as it completely aligns with the engaging nature of mobile access;

- reduce lengthy descriptions including only highly readable content written well;

- facilitate the interest in the subject to attract learners long-lasting attention; 


\section{O. IABUROVA}

Basic Principles of Creating Mobile Learning Content for the Development of

Future Teachers English Language Competence

- follow real people images which look more professional, current, are taken more seriously than clipart and help students stay focused and engaged;

- incorporate modern mobile visual design in learning projects;

- design training exercises which can be completed within 15 minutes or less, thus, this particular duration will allow students to start, complete the exercise, learn the material focused and get experience of accomplishment that encourages them to move on to the next task.

One more principle to be taken into account is mobile mentoring which is growing into importance with the rise of Ukrainian universities which offer the courses for distant students nowadays. The connection with mentors can be organized on an ongoing basis or can provide more real-time, context-aware training opportunities when students need them most.

Mobile mentoring includes recording short, informal videos for common grammar and vocabulary topics in the area of university courses delivered by a group of experienced lectures and tutors who are interested in being mentors to build out the library in the particular course coaching platform. This material, being ubiquitous and reached out at outside university classes, can fill important competency gaps and answer modern students' demands for more mentoring and mobile way of teaching.

Another principle of creating mobile learning content which does not terminate teaching when students complete a course is mobile micro assessments. University staff and mobile mentors create short, five-to-ten question assessments which they schedule to be send students out within weeks or even months after the course completion aimed at testing how much knowledge has been retained. The ways of taking these micro assessments can vary from via text messages without needing to log in to any apps to cloud-based systems.

Knowledge retention is an ongoing concern in modern system of higher education especially when it comes to foreign language learning that can decrease the level of students' competence in basic productive speaking and writing skills if earlier obtained knowledge is not activated and refreshed enough.

Mobile micro assessments can be regarded as the perfect solution for the problem of regular brushing student's knowledge up without requiring them to take time out of their current academic schedules to take a big refresher course in a particular field of English grammar knowledge.

Reasoning for implementing mobile micro assessments into foreign language teaching at universities to be successful is their short duration, convenience and actionable data. Multiple choice micro assessment does not take much time or does not demand students to be destructed from their current activities. Setting a time limit after getting the test notification puts students in a position of relying on their own knowledge rather than asking for their peer assistance or look things up at supplementary grammar references. Micro assessment results analysis can reveal university lecturers specific topic areas where students have mistaken in order to edit and upgrade existing courses or add more training material to be revised. Testing 
frequency and intensity is a discussable question and should be correlated with all university departments not to be overloaded for students.

Following another basic principles for creating mobile learning it is possible to assume that one more reason which motivates many students to experience mobile learning and keep them tracked on a regular basis is an entertaining, engaging and inspiring feature of it. Incorporating appropriate and thoughtful humor based on reallife situations will make students embrace the move from classroom activities to independent learning. Mobile learning content creators can get additional source of inspiration looking around while travelling or getting accustomed to foreign customs and traditions that can enrich their photo and video content with authentic material. These particular tasks filled with lots of hilarity encourage students to be more selfmotivated with regard to their own training success and take the process of learning as the engaging game without being under pressure of being assessed as for grammatically or stylistically correctness.

The conclusions and the perspectives of further research. In the process of doing the research how to use mobile learning content in the forming English language competence of future teachers and making the analysis of the theoretical material and practical experience we can conclude that:

1) the process of mobile learning can be used as one of the most effective way to develop students competence (the development of knowledge and skills) in a particular educational field by the technical means of mobile devices and the specific, informational and didactic content (didactic function), which also play a communicative role in the process of the communication between the lecturer and the participants of the educational process (communication function);

2 ) it is stated out that the main didactic function of mobile learning is forming the system of knowledge, modelling and visualizing particular educational activities, doing educational research, automating the process of controlling and accessing students achievements and supporting students extra-curriculum activity;

3 ) the analysis of mobile learning content leads to the conclusion that the majority of those who are mobile learning users are actively involved in the process of developing foreign languages competence by the means of innovative technologies. Feasibility and effectiveness of using this technology significantly increases students' knowledge.

\section{REFERENCES}

1. Buhaichuk, K. (2012). Mobile learning: essence and models of introduction in educational process of higher educational establishments MIA of Ukraine. Informatsiini tekhnolohii $i$ zasoby navchannia, 1(51), 47-52.

2. Kyslova, M. \& Slovak, K. (2015). Methods of using mobile learning environments IN teaching mathematics of future electromechanical engineer. Informatsiini tekhnolohii $i$ zasoby navchannia. 1(51), 77-81. 
3. Semerikov S. (2015). Development of Mobile Learning Environment as a Problem of the Theory and Methods of Use of Information and Communication Technologies in Education. Informatsiini tekhnolohii i zasoby navchannia, 4(42), 37-39.

4. Striuk, M., Striuk, A., \& Semerikov, S. (2015). Mobility: system approach. Informatsiini tekhnolohii i zasoby navchannia, 5(49), 1-5.

5. Brandsford, M. \& Douglas, J. (2000). How People Learn: Brain, mind, experience, and school. Washington (D.C), USA.

6. Geddes, S. (2004). Mobile Learning in the $21^{\text {st }}$ Century: Benefit for Learners. Retrieved from http://www.voced.edu.au/content/ngv\%3A70571

7. Traxler, J. (n.d.). Defining, Discussing and Evaluating Mobile Learning. Retrieved from www.irrodl.org/index.php/irrodl/article/view/346/857.

\title{
БАЗОВІ ПРИНЦИПИ СТВОРЕННЯ КОНТЕНТУ МОБІЛЬНОГО НАВЧАННЯ ДЛЯ ФОРМУВАННЯ АНГЛОМОВНОЇ КОМПЕТЕНТНОСТІ МАЙБУТНІХ УЧИТЕЛІВ
}

\author{
Олена Ябурова \\ кандидат педагогічних наук, доцент кафедри \\ теорії і практики початкової освіти \\ ДВНЗ «Донбаський державний педагогічний університет» \\ м. Слов'янськ Донецької області, Україна \\ ORCID ID 0000-0003-4633-2900 \\ primetime3311@gmail.com
}

\begin{abstract}
Анотація. Стаття присвячена актуальній проблемі - залученню засобів мобільного навчання та створенню контенту мобільного навчання під час формування англомовної компетентності майбутніх учителів. Автором проаналізовано сучасні наукові роботи, присвячені мобільному навчанню, принципам створення контенту для наповнювання мобільних сайтів, блогів та платформ, вивчено науковий досвід вітчизняних та зарубіжних вчених С. Семерікова, А. Стрюка, М. Стрюка, М. Кислової, М. Бренсфорд, Дж. Дуглас, Дж. Трекслер та інших. Описано базові принципи створення контенту мобільного навчання, які фокусуються на мікро навчанні, гнучкості, підвищенні мотивації до предмету навчання, організації простих візуальних ілюстрацій. Відзначено, що дослідження має практичне значення, оскільки окреслює перспективи впровадження мобільного контенту у процес формування іншомовної компетенції майбутніх вчителів.
\end{abstract}

Ключові слова: мобільне навчання; мобільне середовище; контент мобільного навчання; майбутні вчителі; іншомовна компетенція.

\section{СПИСОК ВИКОРИСТАНИХ ДЖЕРЕЛ}

1. Бугайчук, К. (2012). Мобільне навчання: сутність і моделі впровадження в навчальний процес вищих навчальних закладів МВС України. Інформаційні технологї $i$ засоби навчання, 1(51), 47-52.

2. Кислова, М. (2015). Методика використання мобільного навчального середовища у навчанні вищої математики майбутніх інженерів-електромеханіків. Інформаційні технології $i$ засоби навчання. 1(51). 77-81. 


\section{O. IABUROVA}

Basic Principles of Creating Mobile Learning Content for the Development of

Future Teachers English Language Competence

3. Семеріков, С. (2015). Особливості впровадження мобільного навчання: перспективи, переваги та недоліки. Інформаційні технології $і$ засоби навчання, 4(42), 37-39.

4. Стрюк, М., Стрюк, А. і Семеріков, С. (2015). Мобільність: системний підхід. Інформаційні технології $і$ засоби навчання, 5(49), 1-5.

5. Brandsford, M. \& Douglas, J. (2000). How People Learn: Brain, mind, experience, and school. Washington (D.C), USA.

6. Geddes, S. (2004). Mobile Learning in the $21^{\text {st }}$ Century: Benefit for Learners. Retrieved from http://www.voced.edu.au/content/ngv\%3A70571

7. Traxler, J. (n.d.). Defining, Discussing and Evaluating Mobile Learning. Retrieved from www.irrodl.org/index.php/irrodl/article/view/346/857.

Матеріали надійшли до редакції 14.04.2019 р. 